LINGUACULTURE 2, 2019

\title{
A FEW NOTES ON C.S. LEWIS'S UNDERSTANDING OF THE TAO
}

\author{
Mihaela CERNĂUȚI-GORODEȚCHI \\ Alexandru Ioan Cuza University of Iași, Romania
}

\begin{abstract}
In his series of three lectures delivered at King's College, Newcastle, part of the University of Durham, in February 1943 and published the following year under the title The Abolition of Man; or, Reflections on Education with Special Reference to the Teaching of English in the Upper Forms of Schools, C.S. Lewis passionately argues for the preservation or reinstatement of "the sole source of all value judgements", represented, in his opinion, by "traditional values", that he calls "for convenience the Tao, and which others may call Natural Law or Traditional Morality or the First Principles of Practical Reason or the First Platitudes.” This article looks a little closer at the specific meaning of the Tao selected (and then adapted) by C.S. Lewis from a rather complex and fluid philosophical paradigm informed by two contrasting (Taoist and Confucian, respectively) schools of thought.
\end{abstract}

Keywords: The Abolition of Man, Tao, Taoists, Confucians.

The Abolition of Man (translated for the first time in Romanian by Professor Rodica $\mathrm{Albu}^{1}$ ) is a polemical essay, conveying Lewis's strong reaction to an English teaching book seemingly announcing a very detrimental new educational platform: "Where the old [education] initiated, the new merely 'conditions'. The old dealt with its pupils as grown birds deal with young birds when they teach them to fly: the new deals with them more as the poultry-keeper deals with young birds - making them thus or thus for purposes of which the birds know nothing." (p. 14) What irritates and even angers C.S. Lewis in this otherwise insignificant publication is the ignorant, irresponsible approach of its two authors concerning pupils' feelings. Monumental negligence, in Lewis's

1 „Abolirea omului sau Reflecții asupra educaţiei, cu referire specială la predarea englezei în clasele superioare ale școlilor”. Rodica Albu, ed., Inklings. Litera și spiritul. Iași: Editura Universității „Alexandru Ioan Cuza”, 2004. 85-135 
opinion, since "the head rules the belly through the chest-the seat [...] of emotions organized by trained habit into stable sentiments", which are "the indispensable liaison officers between cerebral man and visceral man. It may even be said that it is by this middle element that man is man: for by his intellect he is mere spirit and by his appetite mere animal.” (p.15)

Firmly convinced that one has to stand against the obvious efforts "to produce what may be called Men without Chests” (p.15), Lewis deems (and denounces) as nefarious any educational or social project like the one that he extensively criticizes here. He believes that intentionally and methodically doing away with people's feelings is not only wrong - it is a wrong done to them and a great sin. It is hubris, since it aims at essentially altering the original design of Nature or Divine Presence. Emotion is not just a luxury for humans, it is a vital mediator between their thought and their primary drives. What Lewis indignantly calls "men without chests" are rather people with atrophied, emptied, no longer functioning chests. Although still normal-looking, although apparently / physically unaffected, such people are hopelessly damaged inside. Turned into pathetic monsters (i.e., into deformed beings), robbed of their potential wholeness, they are almost reduced to the condition of expendable, easily replaceable batteries, having for poles a unilaterally developed, extremely specialized intellect and, respectively, rampant, exacerbated instincts. Such "consumables" are to be produced on a large scale, because, of course, they are in high demand, they are required in a society increasingly dependent on technology, increasingly oblivious to the dangers of neglecting deep and true connection in a misleadingly called "communication era".

The imminent dissolution of humanity (not necessarily triggering, or being accompanied by, the extinction of our species) is the gloomy prospect about which C.S. Lewis sets to warn his contemporaries. Sadly, 75 years later, things do not seem to have changed for the better. It only looks like the spectre glimpsed by him at the horizon has drawn closer. It is difficult to say what chances there are to effectively stop this tragic countdown. It is also difficult to appreciate whether humankind really cares about it anymore. But The Abolition of Man tends to offer one or two solutions to those (be they few or many) still willing to overcome such dire straits.

C.S. Lewis believes that one should always strive to rise above one's biological status. Sense and sensibility are to be cultivated in order to shape a well-rounded personality. Removing "all sentiments, as far as possible, from [one]'s mind" does not increase or strengthen or sharpen brainpower: in C.S. Lewis's words, "a hard heart is no infallible protection against a soft head" (p.10). Moreover, "without the aid of trained emotions the intellect is powerless against the animal organism" (p.14). All traditions (not only those mentioned by Lewis in his essay), each according to its own cultural circumstances and practices, have (implicitly or explicitly) conceived a prototype of the ideal 
human being, whose intellect and emotions are in perfect harmony, whose welldeveloped, well-trained mind, producing a well-structured and well-balanced reasoning, is matched by a good soul and a kind heart, by a caring, understanding, gentle nature. Such an accomplished individual lives in total accord with the Wisdom from Above and in untroubled peace with the surrounding nature and with the fellow humans.

No doubt, the complex code according to which a specific ideal version of humanity takes shape is culturally conditioned. As C.S. Lewis readily admits, bringing together and comparing various such projections might result in finding "many contradictions and some absurdities" (p. 24). "Lump[ing] together [...] the traditional moralities of East and West, the Christian, the Pagan, and the Jew" (p. 24), he says, might seem an odd assortment. "But what is common to them all is something we cannot neglect. It is the doctrine of objective value, the belief that certain attitudes are really true, and others really false, to the kind of thing the universe is and the kind of things we are." (p. 12) "This conception in all its forms, Platonic, Aristotelian, Stoic, Christian, and Oriental alike, I shall henceforth refer to for brevity simply as 'the Tao'”. (p. 24)

Composed of 之/chuò ("brisk walking”) and 首/shǒu ("head”; "first”; "start”, "beginning”; "side”, "direction”; "to face [a direction]”) and having a multitude of meanings (among which: "direction"; "way”, "path”, "road”; "the Way”; "method”, “principle”; "reason”, “truth”, “morality”,2), 道/Tao (or Dao) is a fundamental concept in ancient Chinese philosophy, which has been variously understood, in succession or at the same time, even by local sages and schools of thought. In spite of attributing the Tao to "the Chinese" (in general), Lewis obviously takes into consideration its Confucian interpretation, heavily (and exclusively) quoting from the Analects (論語/Lunyu), while never mentioning or alluding to Laozi or Taoism/Daoism (道教/Dàojia $o^{3}{ }^{3}$ ). No doubt, it would be mean (and utterly unfair) to say that for C.S. Lewis "all Chinese are the same". More probably, as he declares himself not to be "a professional historian" (p. 42), he avoids extending the discussion over things not exactly familiar to himknown only superficially, through only one English translation of one (small) set of relevant texts put together, repeatedly copied and rearranged over the

\footnotetext{
${ }^{2}$ Tao 'means 'path, way, method, or mode of doing a thing,' then also, the mode of expressing a thing, or 'word'; and thus finally it acquires its main meaning, which is 'reason.' As a verb, it means 'to walk, or to tread; to speak or to declare; to argue or to reason.' Considering the religious reverence in which the term is held, the expression Tao, meaning 'word' and 'logical thought' at the same time, presents a close analogy to

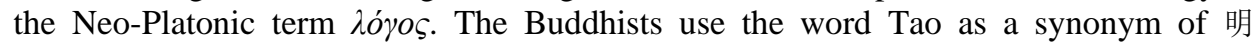
(ming), enlightenment, to translate the Sanskrit बोधि(bôdhi), and the Christians employ it in the version of the New Testament for the term $\lambda \dot{\boldsymbol{o}} \boldsymbol{\gamma} \boldsymbol{o} \varsigma$, 'word.”” (Carus pp. 9-10)

3 教/jiāo means “to tell”; “to teach”, “to instruct”; “teaching”, “religion”.
} 
centuries, in different varieties of an "exotic" analytical language permitting multiple (sometimes very different or even divergent) readings, due to its tendency of letting the context (and the recipient's flair) to decide what exact lexical and/or grammatical meanings are to be selected from fairly large and intricate series.

Obviously, Lewis's understanding of the Tao (and, consequently, his entire argumentation in The Abolition of Man) rests on Waley's translation (1938) of the Confucian Analects. "It is upon the Trunk that a gentleman works" (Waley, p. 83), the motto chosen by C.S. Lewis for the second part ("The Way") of his essay, is in fact a sentence extracted from Master $\mathrm{Yu}^{4 \text {, }} \mathrm{s}$ attempt to obtain advice from Confucius. The disciple's tentative (= inquisitive) intervention continues $^{5}$ : "When that [the trunk] is firmly set up, the Way grows. And surely proper behaviour to parents and elder brothers is the trunk of Goodness?” (p. 83) Waley explains the trunk (his English rendition for the Chinese 本) in a footnote: "i.e. what is fundamental, as opposed to 'the twigs', i.e. small arts and accomplishments, which the gentleman leaves to his inferiors" (p. 83). But other translations do not equate 本 with "trunk", which basically nullifies one major line of reasoning followed by C.S. Lewis in The Abolition of Man: the phrase "Men without Chests" ceases to function as an analogy resting on the polysemy of the word trunk ("bole", "woody stem"; "torso"; "large strong box"). Having in mind the same idea of stability and dependability, most translators into English opt for using "root" as an equivalent for本 in this particular context (Analects 1:2), a choice which also brings to the fore concepts and values (essential for Confucians) such as devotion to origins, respect for foundations and traditions:

The superior man bends his attention to what is radical. That being established, all practical courses naturally grow up. Filial piety and fraternal submission! are they not the root of all benevolent actions? (Legge, p. 2)

The gentleman devotes his efforts to the roots, for once the roots are established, the Way will grow therefrom. Being good as a son and obedient as a young man is, perhaps, the root of a man's character. (Lau, p. 59)

\footnotetext{
${ }^{4}$ Philosopher Yew (Legge) or You Tzu (Lau) or Master Yu (Waley)/You (Watson; Eno) or "You Ruo (有若) was a disciple. For a brief time after Confucius's death, he took on the Master's role for the group of disciples." (Eno)

${ }^{5}$ C.S. Lewis includes the paragraph (Analects 1:2) in the "Appendix. Illustrations of the Tao" (43-4), but (inadvertently, perhaps) he drops the (quite important) question mark from the very end.
} 
The gentleman operates on the root. When the root is firm, then the Way may proceed. Filial and brotherly conduct-these are the root of humaneness, are they not? (Watson, p. 16)

The gentleman applies himself to the roots. Only when the roots are well planted will the Way grow. Filial piety and brotherly obedience are perhaps the roots of humanity, are they not? (Huang, p. 49)

The junzi ${ }^{6}$ works on the root - once the root is planted, the dao is born. Filiality and respect for elders, are these not the roots of ren $^{7}$ ? (Eno)

Ironically, although it cancels his wordplay on trunk - chest, the 本-“root” is much more coherent (than 本_“trunk”) with C.S. Lewis's leaning towards the Confucian "version” of the Tao - a practical approach, functioning as a code of moral conduct and proposing a recognizable way of self improving (see, for instance, "Chün-tzu, the gentleman or cuor gentil”, 21). This understanding of the Tao really suits Lewis's arguments-which can hardly be said about Laozi's or Zhuangzi's (respective) Tao(s). From Tao Te Ching one learns, for instance, that Tao (sometimes translated as "Way" or "Reason") is "the Whole", something literally indefinable, since words, in charge of marking the boundary between what a thing is and what it is not, have absolutely no boundary to signal here, because beside "the Whole" there can be nothing else:

The Tâo that can be trodden is not the enduring and unchanging Tâo./ The name that can be named is not the enduring and unchanging name. (Legge, p. 47)

The reason that cannot be reasoned is not the eternal Reason./ The name that cannot be named is not the eternal Name. (Carus, p. 97)

The Tao that can be understood cannot be the primal, or cosmic, Tao, just as an idea that can be expressed in words cannot be the infinite idea. (Goddard, p. 11)

The way that can be spoken of/ Is not the constant way;/ The name that can be named/ Is not the constant name. (Lau, p. 5)

\footnotetext{
6 “Junzi 君子: Originally 'a prince'; used by the Analects to denote an ideal moral actor. The term is sometimes rendered 'gentleman', but has a more emphatic moral sense, and is left untranslated here. At times it merely denotes a ruler.” (Eno)

7 “Ren 仁: The key moral term in the Analects. Rendered as 'humanity,' 'goodness,' etc., its rich meaning is a mystery to many in the text, and defies translation.” (Eno)
} 
The ways that can be walked are not the eternal Way;/ The names that can be named are not the eternal name. (Mair, p. 59)

In Laozi's philosophy, Tao is not to be actively pursued; “virtue is simply 無為 (wu-wei) or 'not acting, not making, not doing'” (yin versus yang), which "cannot mean inactivity, for it is with Lao Tze a principle of action" (Carus, p. 18); it is "not forcing the nature of things", it is "the surrender of attachment to self and the utter omission of 人道 (jhren tao), i.e., of man's Tao, the peculiar and particular Tao of oneself and following the course prescribed by the eternal Tao, 常道 (ch'ang tao); “it is, briefly, not 'non-action,' but 'non-assertion’” (Carus, p. 19).

As one of Laozi's disciples, Zhuangzi also distinguishes between "the Tao, or Way, of Man" and "the Tao, or Way, of Heaven", noting that they are "far apart", if not antithetical: "Doing nothing and yet attracting all honour is the Way of Heaven; Doing and being embarrassed thereby is the Way of Man." (Legge, Book XI, 306) "To rest in inaction, and command respect-this is the Way of Heaven. To engage in action and become entangled in it-this is the way of man." (Watson 125) Treading the way of man is, in fact, erring from the Way of Heaven. Thinking that one has found the Way, one has thoroughly lost it, without even realizing one's error. The Way is-and should be accepted as-a total mystery; seizing it is impossible for human mind and senses:

The Tâo cannot be heard; what can be heard is not It. The Tâo cannot be seen; what can be seen is not It. The Tâo cannot be expressed in words; what can be expressed in words is not It. [...] the Tâo does not admit of being named. [...] If one ask about the Tâo and another answer him, neither of them knows it. Even the former who asks has never learned anything about the Tâo. He asks what does not admit of being asked, and the latter answers where answer is impossible. (Legge, Book XXII, p. 69)

The Way [Tao] cannot be heard; heard, it is not the Way. The Way cannot be seen; seen, it is not the Way. The Way cannot be described; described, it is not the Way. [...] There is no name that fits the Way. [...] He who, when asked about the Way, gives an answer does not understand the Way; and he who asked about the Way has not really heard the Way explained. The Way is not to be asked about, and even if it is asked about, there can be no answer. (Watson, pp. 243-4)

In strong contrast with Taoists (but resembling other-more familiar to C.S. Lewis-lines of thought and beliefs), the paternalist and practical Confucian view of Tao indicates reassuring connections between Heaven and Earth. Instead of discouraging action and the imitation impulse, it states that a Supreme Power residing high above rules the entire universe as an omnipotent and omniscient 
righteousness and continually guides the willing humans in their efforts of mirroring (more or less precisely) the celestial state of things. In this vein, C.S. Lewis mentions in The Abolition of Man the Sanskrit ṛta (ऋत) and satyá (सत्य) from Vedic and post-Vedic texts:

In early Hinduism that conduct in men which can be called good consists in conformity to, or almost participation in, the Rta - that great ritual or pattern of nature and supernature which is revealed alike in the cosmic order, the moral virtues, and the ceremonial of the temple. Righteousness, correctness, order, the Rta is constantly identified with satyá or truth, correspondence to reality. [...] the Indian masters say that the gods themselves are born of the Rta and obey it. (p. 11)

Immediately after briefly explaining the two Hindu concepts, Lewis remarks: "The ancient Jews likewise praise the Law as being 'true"" and details (in an endnote) the meaning of the Hebrew concept of ěmeth (şֶ), "truth": "Where the satya of the Indian sources emphasizes truth as 'correspondence', ěmeth (connected with a verb that means 'to be firm') emphasizes rather the reliability or trustworthiness of truth.” (11) One could add that ěmeth is related to the verb aman (אֵָָ), meaning "to support", "to confirm" and to the interjection amen (אָמֵ), "surely", "in truth", "so be it". Since in the "Appendix" he extensively cites from the 42 Divine Principles of Maat, listed in the Confession of the Righteous Soul, to be found in The Papyrus of Ani (or the Book of Coming Forth By Day or The Egyptian Book of the Dead) ${ }^{8}$, Lewis could surely have mentioned on an equal footing the maat/ma'at of the Ancient Egyptians, meaning "truth", "justice", "fairness", "right action", "righteousness", "right order (in the cosmos/state)", a noun belonging to the same lexical family as the verb maa, signifying "to direct", "to guide", "to be true", "to be just".

But rta and satyá, ěmeth or maat are abstract notions, while Tao, especially in its Confucian version, beside "the Way in which the universe goes on" (p. 11), also designates a material road, which helps projecting "the Way which every man should tread in imitation of that cosmic and supercosmic progression" (p. 12).

Last, but not least, maybe C.S. Lewis chooses the Confucian Tao because it is an appropriate metaphor for what he has in mind when he sets his heart on figuring a "vaccine" against the fast approaching "disease" that is a huge threat to individuals and society alike. He feels it is all about control when he warns against "Man's [deceptive] conquest of Nature", "an expression often used to describe the progress of applied science" (p. 28). In order to get the

\footnotetext{
8 "I have not slain men [or women]." "I have not been grasping." "I have not stolen." "I have not spoken falsehood.” And so on - see Lewis 42-8.
} 
power over things or people, one needs to understand how they function-for which purpose it could be worth considering simplifying them as much as possible. This is why the so-called (by Lewis) Conditioners aim to produce "men without chests". "It is not that they are bad men. They are not men at all. Stepping outside the Tao, they have stepped into the void. Nor are their subjects necessarily unhappy men. They are not men at all: they are artefacts" (p. 33), "slaves and puppets of that to which [they] have given [their] souls" (p. 37). How can such a dismal prospect be avoided? C.S. Lewis suggests it would be helpful to remember that life may be transient, but humans are able to decide how they want to follow their paths: "Only the Tao provides a common human law of action which can over-arch rulers and ruled alike. A dogmatic belief in objective value is necessary to the very idea of a rule which is not tyranny or an obedience which is not slavery.” (p. 37)

Following the stars in the sky above him and abiding by the moral law within him, man can experience the freedom of redefining himself through his meaningful journey from birth to death. The Tao can teach him how to plan his journey, what destination(s) to choose, how to continually readjust his goals and desires, how to put things in perspective-how to harmonize the Way and his way.

\section{Works Cited}

Lewis, Clive Staples. The Abolition of Man; or, Reflections on Education with Special Reference to the Teaching of English in the Upper Forms of Schools. Oxford University Press - London: Humphrey Milford, 1944. Print

\section{Confucius/Kong(fu)zi Translations/Editions in English}

Eno, Robert, ed. "The Analects of Confucius. An Online Teaching Translation” (Version 2.21). www.indiana.edu. Indiana University Bloomington. 2015. Web. 12 February 2019

Huang, Chichung, ed. The Analects of Confucius: A Literal Translation with an Introduction and Notes. Trans. Chichung Huang. Oxford: Oxford University Press, 1997. Print.

Lau, D.C., ed. The Analects. Trans. D.C. Lau. London: Penguin, 1979. Print.

Legge, James, ed. "Confucian Analects". The Chinese Classics with Translation, Critical and Exegetical Notes, Prolegomena, and Copious Indexes. Trans. James Legge. London: Trübner \& Co., 1861. Vol. 1. [The Body of the Volume] 1-218. Print.

Waley, Arthur, ed. The Analects of Confucius. Trans. Arthur Waley. London: George Allen \& Unwin ltd., 1938. Print.

Watson, Burton, ed. The Analects of Confucius. Trans. Burton Watson. New York: Columbia University Press, 2007. Print. 


\section{Laozi/Lao Tze/Lao Tzu Translations/Editions in English}

Borel, Henri, “Wu Wei”. Trans. M.E. Reynolds. Laotzu's Tao and Wu Wei. New York: Brentano’s Publishers, 1919. 55-116. Print.

Carus, Paul, ed. Lao-Tze's Tao-teh-king. Chinese-English, with introduction, transliteration, and notes. Trans. Dr. Paul Carus. Chicago: The Open Court Publishing Company, 1898. London: Kegan Paul, Trench, Truebner \& Co., 1898. Print.

Goddard, Dwight, ed. “Laotzu’s Tao”. Laotzu's Tao and Wu Wei. Trans. Dwight Goddard. New York: Brentano’s Publishers, 1919. 7-53. Print.

Lau, D.C., ed. Tao Te Ching: The Book of the Way and Its Virtue. Trans. D.C. Lau. Middlesex, England: Penguin Books, 1963. Print.

Legge, James, ed. “The Tâo Teh King or the Tâo and Its Characteristics”. The Sacred Books of China: The Texts of Taoism. Trans. James Legge. Ed. F. Max Müller, The Sacred Books of the East. Vol. 39. Oxford: Clarendon Press, 1891. 45-124. Print.

Mair, Victor H., ed. Tao Te Ching: The Classic Book of Integrity and The Way. A new translation by Victor $H$. Mair, based on the recently discovered Ma-wang-tui manuscripts. New York: Bantam Books, 1990. Print.

Waley, Arthur, ed. The Way and its Power: A Study of the Tao Te Ching and its Place in Chinese Thought. Trans. Arthur Waley. Boston: Houghton Mifflin, 1934. Print.

\section{Chuang Tzu/Kwang-dze/Zhuangzi Translations/Editions in English}

Legge, James, ed. “The Writings of Kwang-dze. Books I-XVII”. The Sacred Books of China: The Texts of Taoism. Trans. James Legge. Ed. F. Max Müller, The Sacred Books of the East. Vol. 39. Oxford: Clarendon Press, 1891. 164-392. Print.

Legge, James, ed. “The Writings of Kwang-dze. Books XVIII-XXXIII”. The Sacred Books of China: The Texts of Taoism. Trans. James Legge. Ed. F. Max Müller, The Sacred Books of the East. Vol. 40. Oxford: Clarendon Press, 1891. 1-232. Print.

Watson, Burton, ed. The Complete Works of Chuang Tzu. Trans. Burton Watson. New York: Columbia University Press, 1968. Print.

Mihaela Cernăuți-Gorodețchi is a professor in the Department of Comparative Literature, Faculty of Letters, “Alexandru Ioan Cuza” University of Iași. Her research interests and areas of expertise are: world and comparative literature (Oriental literatures; famous fairy tales collections; Romanticism and fairy tales; modern and postmodern fairy tales; fantasy; children's literature); world theatre history; literature and the visual arts. She authored several books: Poetica basmului modern [A Poetics of Modern Fairy Tales], 2000/2002; Dicţionar de personaje carrolliene [Lewis Carroll's Characters: A Dictionary], 2003; (with Gyorfi-Déak György \& Robert Lazu) Enciclopedia lumii lui J.R.R. Tolkien [A Tolkien Encyclopedia], 2007; Literatura pentru copii. Sinteză critică [Children's Literature], 2008.

Email:micer@uaic.ro 
